\title{
The River Influence Controls Water Quality and Spatio-Temporal Microalgal Distribution in Pacific Estuaries (Padre Ramos and Salinas Grandes) of Nicaragua
}

\author{
Carmen Rojo ${ }^{1, * \mathbb{C}}$, Dalia Lumbi ${ }^{2}$, Ariel Aguilar ${ }^{2}$, Karen Palacios ${ }^{2}$, Katherine Osorio ${ }^{2}$ and Pilar Ruiz ${ }^{1}$ \\ 1 Cavanilles Institute for Biodiversity and Evolutionary Biology, University of Valencia, \\ Catedrático José Beltrán 2, E-46980 Paterna, Spain; Pilar.Ruiz@uv.es \\ 2 Animal Physiology Laboratory, National Autonomous University of Nicaragua (UNAM-León), \\ Central Building, Next to La Merced Church, León P.O. Box 68, Nicaragua; \\ dalia.lumbi@ev.unanleon.edu.ni (D.L.); arielaguilar@ev.unanleon.edu.ni (A.A.); \\ karen.palacios@ev.unanleon.edu.ni (K.P.); katherinne.osorio@ev.unanleon.edu.ni (K.O.) \\ * Correspondence: Carmen.Rojo@uv.es
}

check for updates

Citation: Rojo, C.; Lumbi, D.; Aguilar, A.; Palacios, K.; Osorio, K.; Ruiz, P. The River Influence Controls Water Quality and Spatio-Temporal Microalgal Distribution in Pacific Estuaries (Padre Ramos and Salinas Grandes) of Nicaragua. Water 2021, 13, 1712. https://doi.org/10.3390/ w13121712

Academic Editors: Martín

Merino-Ibarra, Salvador

Sánchez-Carrillo and Javier

Alcocer-Durand

Received: 14 May 2021

Accepted: 18 June 2021

Published: 21 June 2021

Publisher's Note: MDPI stays neutral with regard to jurisdictional claims in published maps and institutional affiliations.

Copyright: (c) 2021 by the authors. Licensee MDPI, Basel, Switzerland. This article is an open access article distributed under the terms and conditions of the Creative Commons Attribution (CC BY) license (https:/ / creativecommons.org/licenses/by/ $4.0 /)$.

\begin{abstract}
Estuaries are coastal wetlands that deserve special attention because they are vulnerable, biodiversity- and service-rich environments. However, estuaries of tropical areas have been scarcely studied regarding water quality and biodiversity in spite of strong developments of their agricultural and livestock sectors. Two estuaries on the Pacific Nicaragua in which snapper cages had been set up were studied regarding water physicochemical properties, microalgae and cyanobacteria along with their dynamics over a hydrological year. Both environments showed excellent water quality (oligotrophy and absence of harmful organisms) arising from their fluvial features. During the rainy season, there was a decline in chemical compounds and microorganisms. In the dry period nutrients and salinity promoted different assemblages of microscopic primary producers that were never too dense. Nutrient inputs from shrimp farms, agricultural crops and snapper cages did not appear to increase eutrophication and cyanobacterial blooms did not occur. Furthermore, the strong fluvial character of these estuaries seems to prevent the entry of harmful dinoflagellates from marine areas.
\end{abstract}

Keywords: snapper cages; shrimp farms; cyanobacteria; harmful algae; hydrology; salinity; nitrate

\section{Introduction}

The ecological and service value of wetlands, especially coastal wetlands, is now recognized. We also know that they are highly vulnerable to global changes [1], such as changes in sea level, desiccation, deforestation or the abusive use of pesticides [2-4].

However, the amount of available information related to coastal wetlands in different parts of the planet is not comparable; temperate zones have been studied in greater depth compared to tropical ones. A paradigmatic example is the scarcity of information concerning the estuaries of Central America. These wetland areas have a high level of biodiversity; they help to control the coastlines in the face of rising sea levels, and their fish and bivalves, etc. are the source of livelihood for an impoverished and vulnerable population. Moreover, before we get the chance to learn more about them, they are being profoundly altered by farms upstream, or in their catchment area [5], due to extensive shrimp aquaculture, whose exploitation is not always controlled, or deforestation and extensive agriculture which produces inputs of allochthonous material (i.e., pollutants, loads of organic and inorganic material, etc.) as well as extreme climatic processes [6,7] among other factors. On the other hand, coastal processes also affect estuary waters, hence toxic tidal events can end up damaging the biota of the estuaries [8] and, more recently, the over-exploitation of coastal fish with a market value, such as the spotted rose snapper (Lutjanus guttatus), endangers the symbiosis of fishing communities linked to the estuaries. These issues should be viewed as a One Health concern [9]. 
Despite this evidence, coastal wetlands, such as the estuaries of the tropical or subtropical Pacific coast, have hardly been studied, and very few of them receive special attention. Those that are being studied the most, and can serve as a reference for new studies on water quality and the connection of aquatic biodiversity with biogeochemical processes, are in Costa Rica, such as the highly productive tropical Gulf of Nicoya estuary [10-13]. Different areas in the Gulf of California (Mexico) have also been studied due to their interest in aquiculture and concern about harmful algae [14,15]. In Nicaragua, research studies which have been published internationally are almost exclusively about the Estero Real. For example, and without being exhaustive, we can cite: the concern, since the late 1990s, about the extension of its shrimp aquaculture at the expense of the mangrove and its possible pollutants [16,17]; studies related to its high biodiversity [18]; comparisons of the limnology of its ponds with other coastal wetlands [19,20], and the monitoring of harmful algae [21,22]. Along with the Estero Real, the other coastal wetlands of interest are the Estero de Padre Ramos (EPR hereafter) and Estero de Salinas Grandes (ESG hereafter) $[6,18]$.

The EPR and ESG are no more than $90 \mathrm{~km}$ from each other, so regional effects are not expected to differentiate them [23] and the orientation of their course with respect to the sea and their openings to it are similar. Therefore, the local factor that ultimately explains their different physicochemical characteristics and the development of their biodiversity is the use of the land around them, within their catchment areas. Farm land, shrimp farms and livestock farms are determining factors in the contributions of nutrients and other compounds, such as pesticides, which the estuaries receive [17,24]. For this reason, the rains, as a dragging or leaching mechanism towards the course of the estuary, could mean an increase in these compounds, and the tides, or the greater marine intrusion, could act as a diluent [25]. On the contrary, there may be a dilution of the compounds which are already in the estuary in the Gulf of Nicoya [13] during the rainy season, or the marine intrusion in the dry season, when upwelling occurs, could contribute nutrients to the estuary, as described for the Drakes Estero in California [26].

Recently, snapper farms have been advocated in these two estuaries (EPR and ESG) on the Pacific coast of Nicaragua to be exploited by the local communities themselves. The monitoring of the possible impact of these facilities has been studied in several international projects (e.g., [27]). These projects have made it possible to analyze some limnological variables, such as the salinity, the concentration of nutrients and the primary planktonic producers such as microalgae and cyanobacteria (MIC hereafter) in extensive areas of these estuaries over a hydrological year. Using this information, in this work we intend to verify, for the first time, the health status of these wetlands and to suggest what are the control factors of their primary planktonic producers, the basis of the biodiversity and the production of such ecosystems.

Salinity is a determining factor in MIC biodiversity and nutrient cycles [24], and it should be taken into account in anticipation of a greater marine influence $[6,28]$. Nutrients are a good indicator of the potential for eutrophy and the load of allochthonous compounds that the estuary is receiving, for example, from shrimp farms [6] or crops [4]. In addition, it is relevant to analyze the abundance and composition of MIC, both of plankton and resuspended benthos because: (a) their biomass is a recognized indicator of eutrophy [29,30]; (b) some populations are indicative of changes in the environment that may not be detected in time (i.e., salinization, eutrophication), and (c) they are more accessible systems than the open sea to detect the early presence of harmful populations of marine origin [8], or freshwater cyanobacteria from, for example, shrimp ponds [31].

We are aware of the possible limitations of this work, but we consider that this is a first effort and a basis, or starting point, if we want to see the evolution of these systems in the face of global change and exploitation, and to implement management strategies from the Ecosystem Approach to Fisheries and Aquaculture [32] and One Health [9]. 


\section{Materials and Methods}

\subsection{Study and Sampling Sites}

The EPR Natural Reserve and the ESG are both located in the Pacific region of Nicaragua [33,34]. The EPR can be found between the port of Corinto and the peninsula of Cosigüina (Department of Chinandega), and the ESG is next to the municipality of León (Department of León) (Figure 1a).
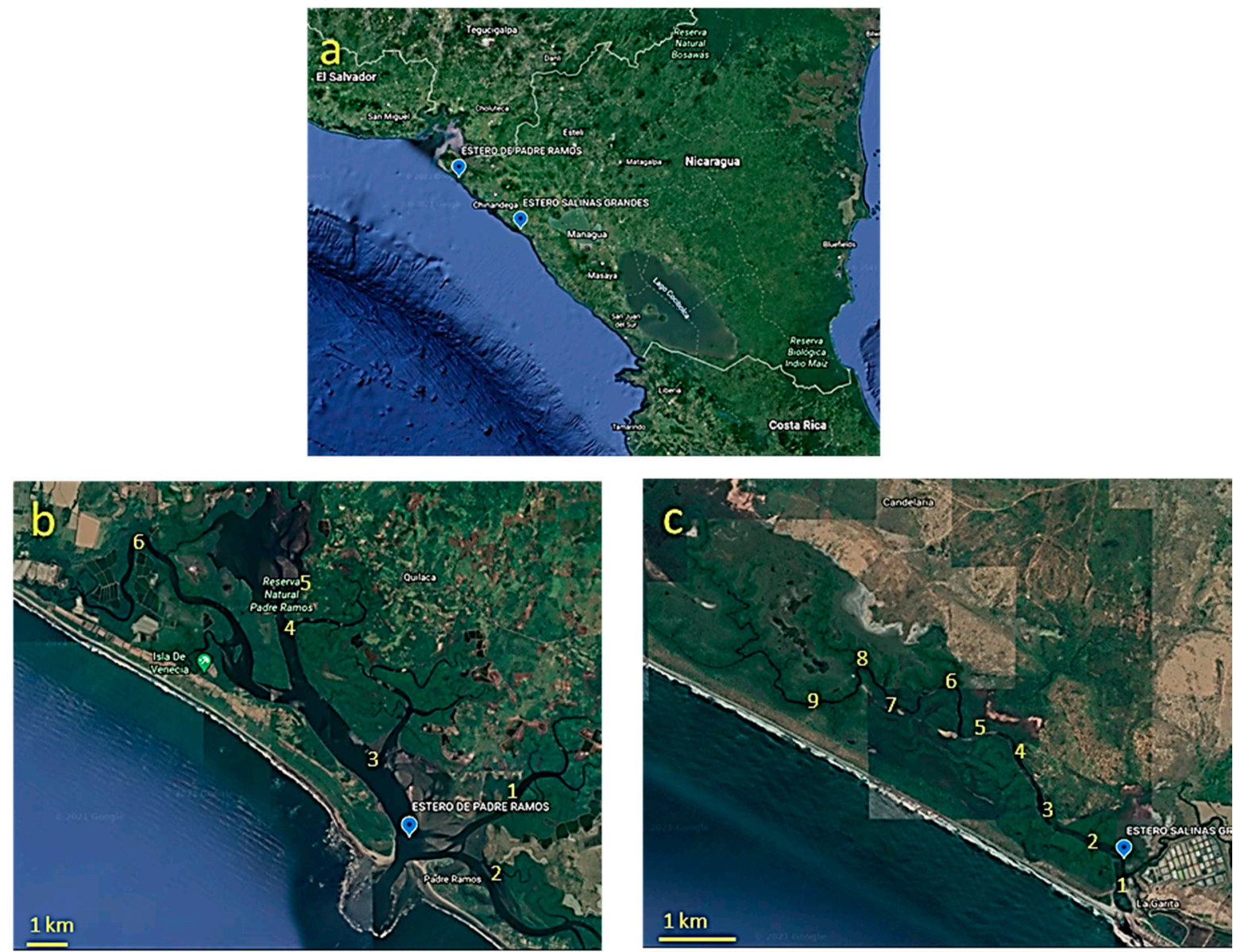

Figure 1. (a) Estero del Padre Ramos (EPR) and Estero Salinas Grandes (EGS), located on the Pacific coast of Nicaragua. (b) The six sampling sites in the Estero del Padre Ramos. (c) The nine sampling sites in the Estero Salinas Grandes. Sites names and their coordinates are given in Table S1 (Supplementary material). Pictures from Google Maps and Earth 2021.

The EPR includes mangroves, beaches, shrimp farms, islets, etc. The ESG also houses beaches where salt is currently produced [33]. Both have a dry, warm climate, a tropical savanna climate according to the Köppen classification, with a dry season from November to April and a wet season the rest of the year. Rainfall is 1500-1800 mm per year [35]. Temperatures fluctuate around 36 degrees Celsius. The winds are strong in the dry season, and they are intensified between February and April, reaching speeds of up to $30 \mathrm{~km} / \mathrm{h}$ [33]. Sampling took place in April, September, October, November and December 2018, and January and February 2019; the exact days were chosen to ensure that the high tide occurred between 9-12 am to allow transport by boat along the course of the estuaries, whose depth was approximately $5 \mathrm{~m}$. In EPR, six sites were sampled (Figure 1b); the extremes being in Poza de la Vaca $\left(12^{\circ} 50^{\prime} 20.9^{\prime \prime} \mathrm{N}, 87^{\circ} 32^{\prime} 33.2^{\prime \prime} \mathrm{W}\right)$ and El Sistema $\left(12^{\circ} 45^{\prime} 20.9^{\prime \prime} \mathrm{N}\right.$, $\left.87^{\circ} 27^{\prime} 21.0^{\prime \prime} \mathrm{W}\right)$. All the sites had a floating cage nearby for the rearing of snapper, except for Quilaca (site P4). In the EPR, the distance between the furthest sites is $13.5 \mathrm{~km}$, extending to $19 \mathrm{~km}$ if we include the derivations (Figure 1b). In ESG, 9 sites were sampled between La Garita (12 $\left.16^{\prime} 22.0^{\prime \prime} \mathrm{N} 86^{\circ} 52^{\prime} 47.3^{\prime \prime} \mathrm{W}\right)$ and Corcovado $\left(12^{\circ} 17^{\prime} 52.2^{\prime \prime} \mathrm{N} 86^{\circ} 54^{\prime} 56.2^{\prime \prime} \mathrm{W}\right)$; 
these sites are found along the Chiquito river, a distance of $7.5 \mathrm{~km}$ (Figure 1c). The only site with a snapper cage was Garita (site P1). All the sites were geo-referenced (Table S1). The snapper cages are $5 \times 5 \times 5 \mathrm{~m}$ cubic bags and their maximum production is $1800 \mathrm{~kg}$ of snapper in 8 months.

\subsection{Obtaining Variables In Situ, Sampling and Analysis}

Salinity, dissolved oxygen, $\mathrm{pH}$ and temperature were measured a few centimeters below the surface, at the middle depth of the water column and $20 \mathrm{~cm}$ from the bottom; the data did not vary significantly and were averaged. When the sampling location was near a floating cage for snappers, measurements were taken after having gone past the cage in the direction of the current. Dissolved oxygen (DO, $\mathrm{mg} / \mathrm{L})$ was measured with a Handheld Multiparameter Instrument oximeter (model 556, YSI), and salinity (ppm) was measured with a handheld salinity refractometer (J\&G SC). The $\mathrm{pH}$ was measured using a $\mathrm{pH}$ meter (Eco Testr $\mathrm{pH} 2)$, and Transparency $(\mathrm{cm})$ was measured using a Secchi disk.

Using a hydrographic bottle, $2 \mathrm{~L}$ of water were extracted at the middle depth of the water column. Then, $1 \mathrm{~L}$ of this water was used to carry out the chemical analyses and it was kept refrigerated; the other liter of water was fixed with lugol for the subsequent study of the MIC. Both samples arrived for processing at the UNAN-León laboratory on the same day the sampling took place.

To obtain the nitrate, ammonium and orthophosphate concentration, the reagents from the MQuantTM test strips kit (Merck [35,36]) were used.

The liter of sampled water settled for three days in $250 \mathrm{~mL}$ test tubes in order to be able to concentrate the seston in $20 \mathrm{~mL}$, the volume that was used in the analysis. The taxonomic classification and measurement of the body-size of the most abundant populations were done with a conventional LW microscope at $400 \times$ magnification. The taxonomic classification of the MIC was carried out, differentiating between the large groups of algae: Chlorophytes, Diatoms, Dinophytes, Euglenophytes and Cyanobacteria [37]. The organisms were identified at the finest possible taxonomic resolution following standard references (cited in [38]) as well as some local recommendations for organisms of possible marine origin and from tropical areas [39-41]. For the counting and subsequent calculation of the population densities, Neubauer and Sedgwick-Rafter chambers [42] were used to analyze the $20 \mathrm{~mL}$ concentrate at $100 \times$ magnification; both chambers were filled and counted six times to get average values. Algal biomass (expressed as biovolume, $\mathrm{mm}^{3} / \mathrm{L}$ ) was calculated with density and cell volume, measuring sizes from at least 20 individuals and following [43]. The total chlorophyll $a$ concentration was estimated taking into account the chlorophyll $a$ concentration per unit of biovolume established for each MIC group by [37].

\subsection{Statistical Analysis}

Means comparisons were carried out with repeated measure ANOVA (post-hoc Tukey's pairwise test). Compliance with the requirements was verified (normality with the Shapiro-Wilks test; homogeneity with the Levene test). When these did not comply, a non-parametric comparison was made, obtaining the Kruskal-Wallis H (post-hoc MannWhitney's test). Principal components analysis (based on correlation coefficient; [44]) was carried out to order samples and their limnological variables (temperature, $\mathrm{pH}$, dissolved oxygen, salinity, concentration of nitrate, ammonium and orthophosphate plus MIC biovolume). Canonical Correspondence Analysis (CCA; [45]) was also used. CCA of the sites and taxa abundance, where each site has given values for the seven physico-chemical environmental variables. Thus the taxa abundances are considered to be a response to the environmental variables gradient. The calculations were done using the free statistical program package PAST [46]. 


\section{Results}

\subsection{Limnology of the Estero del Padre Ramos}

The temperature range throughout the year studied, including all the sites, was 27.7-31.2 ${ }^{\circ} \mathrm{C}$. A decreasing trend can be observed from the first to the last month of sampling (Figure 2). The ANOVA analysis highlighted two thermal seasons (Table S2): April to September with $30.4 \pm 0.6{ }^{\circ} \mathrm{C}$, and October to February with $28.5 \pm 0.6{ }^{\circ} \mathrm{C}$ (mean \pm standard deviation). The $\mathrm{pH}$ range varied between 7.5-8.7, and showed three periods (Table S2): from April to October, from November to January, and February, with averages of $7.8 \pm 0.3,8.4 \pm 0.3$ and $8.3 \pm 0.2$, respectively (Figure 2). The DO concentration range was 3.1-7.2 $\mathrm{mg} / \mathrm{L}$ (Figure 2). Three significantly different mean periods were observed (Table S2): April ( $4.3 \pm 0.4 \mathrm{mg} / \mathrm{L})$, from September to November $(5.1 \pm 0.7 \mathrm{mg} / \mathrm{L})$ and from January to February $(6.5 \pm 0.5 \mathrm{mg} / \mathrm{L}$ ). Salinity (Figure 2) fluctuated between $20 \mathrm{ppm}$ and $36 \mathrm{ppm}$, and the annual means were significantly different (Table S2). From lowest to highest, the salinity ranges were: September-October (26.4 $\pm 3.7 \mathrm{ppm})$, April and November $(32.5 \pm 2.1 \mathrm{ppm}$ and $32.7 \pm 1.8 \mathrm{ppm})$ and January-February (35.2 $\pm 1.8 \mathrm{ppm})$.
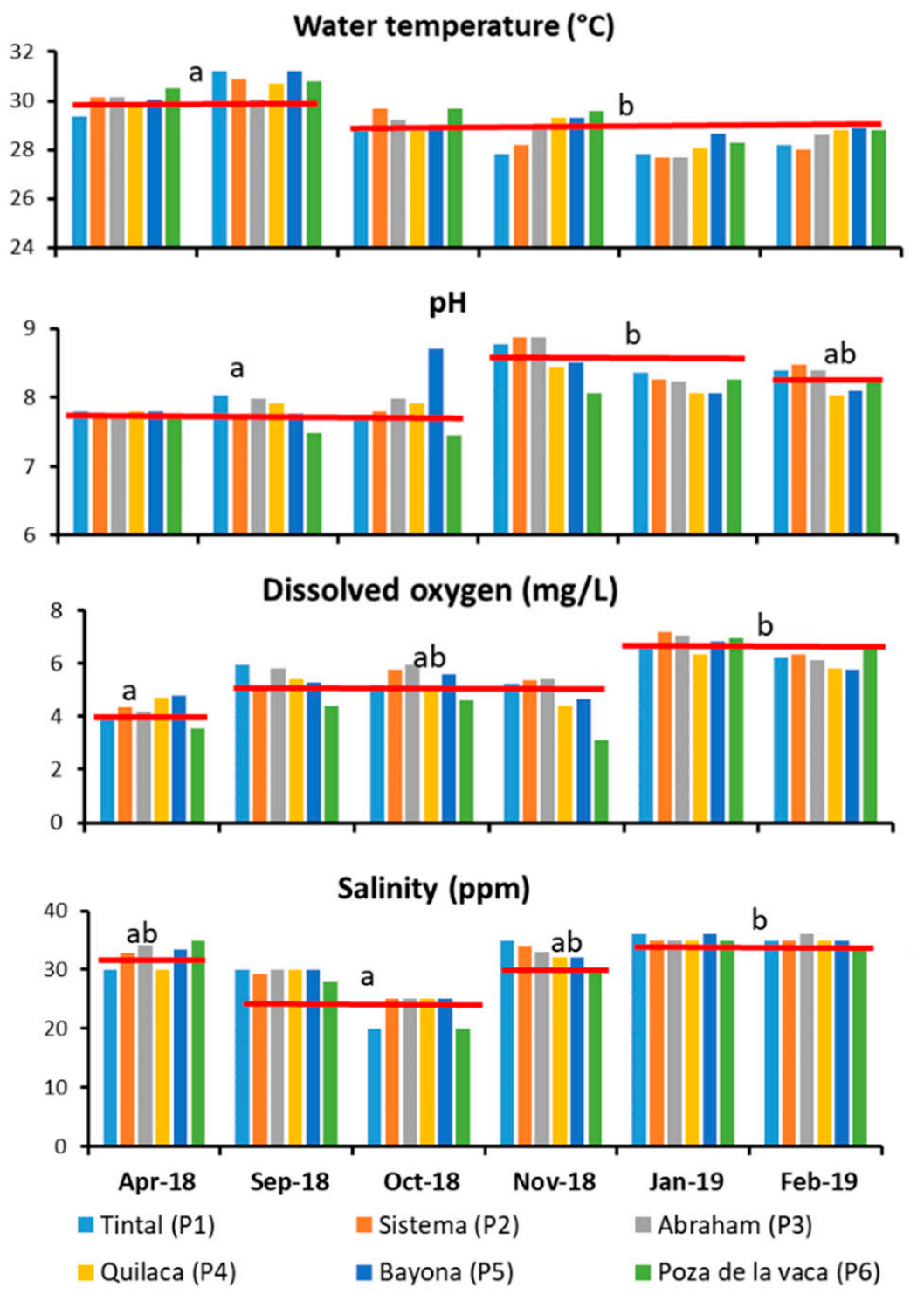

Figure 2. Physicochemical variables measured in the six sites of the Estero del Padre Ramos. Red lines show the mean of each different group based on the ANOVA results (Table S2; Supplementary material). The lower-case letters indicate significant differences in pairwise comparisons. Significant values when $p<0.001$. 
Nitrate concentration varied between undetectable values and $12 \mathrm{mg} / \mathrm{L}$, and two periods were observed (Figure 3; Table S2). The minimum concentrations were from April to November, while the period from January to February had an average concentration of $9.2 \pm 1.6 \mathrm{mg} / \mathrm{L}$. The ammonium concentration was minimal from April to January at all the sites, and increased in January and February; as was the case with nitrate. However, in these last two months a great variation between sites was observed, from undetectable concentrations to $2.5 \mathrm{mg} / \mathrm{L}$ in Poza de la Vaca (Figure 3); an ANOVA indicated that there were no significant differences between months. The orthophosphate concentration (mg/L) varied considerably between the sites on each sampling date (Figure 3; Table S2), and it was higher in September and October $(0.025 \pm 0.024 \mathrm{mg} / \mathrm{L})$, with peaks at two sites near the estuary mouth (P1-P3; Figure 1b).
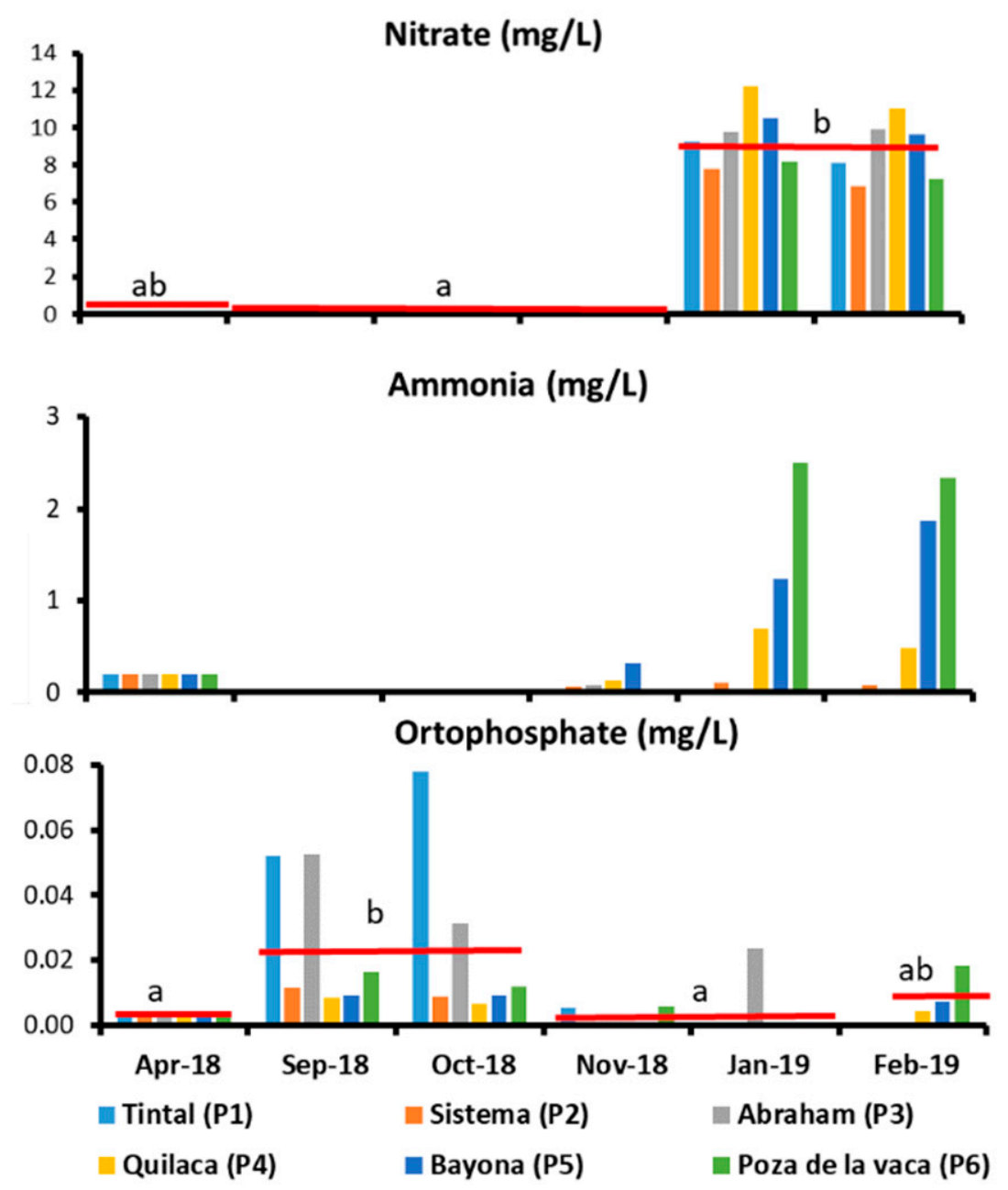

Figure 3. Nutrient concentrations measured in the six sites of the Estero del Padre Ramos. Red lines show the mean of each different group based on the ANOVA results (Table S2; Supplementary material). The lower-case letters indicate significant differences in pairwise comparisons. Significant values when $p<0.001$.

The average MIC biovolume decreased from April 2018 to February 2019 (Figure 4). The range was $0.15 \pm 0.15 \mathrm{~mm}^{3} / \mathrm{L}$ (mean and standard deviation) in April, and $0.04 \pm 0.01 \mathrm{~mm}^{3} / \mathrm{L}$ in January 2019. The spatial variability decreased over time (the coefficient of variation was 102 in April and 34 in February, Figure 4). The averages were not statistically different. There were no differences in the mean biovolume over time calculated for each sampling site (Figure 4). The estimated chlorophyll $a$ concentration covaried with the biovolume $\left(R^{2}=0.85, p<0.001\right)$. Estimated chlorophyll $a$ did not exceed 
$2.3 \mu \mathrm{g} / \mathrm{L}$, nor did it show significant differences between months. It ranged between $1.04 \pm 0.70 \mu \mathrm{g} / \mathrm{L}$ (April) and $0.45 \pm 0.10 \mu \mathrm{g} / \mathrm{L}$ (January).
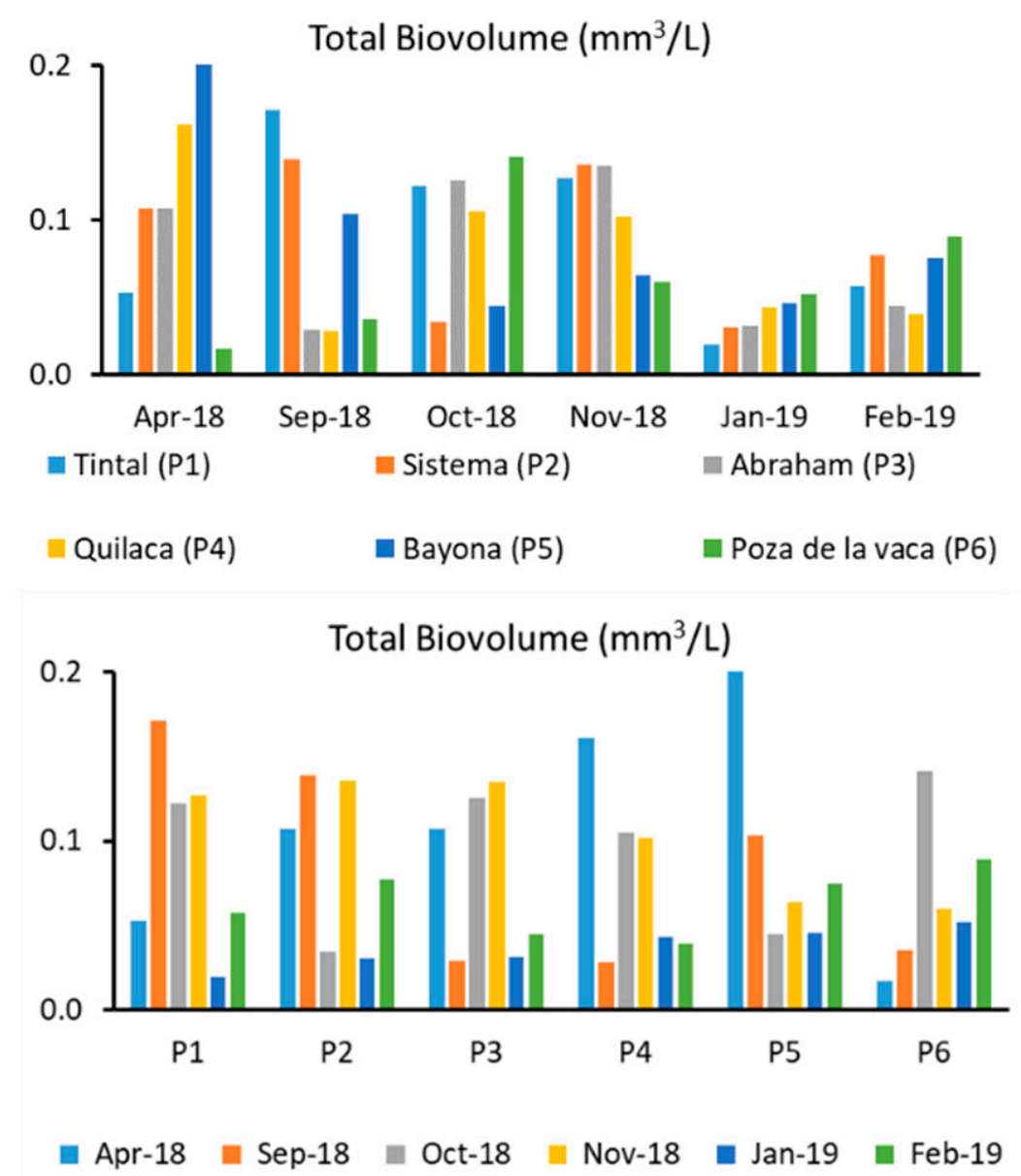

Figure 4. Biovolume of microalgae and cyanobacteria (MIC) estimated for the six sites of the Estero del Padre Ramos over the sampling period (upper graph) and temporal dynamics of biovolume in each site (bottom graph).

The ordering into main components (Figure 5a) chronologically separates the samples from the EPR. The April, September and October samples are located in the negative section of component 1 , together with a higher biovolume concentration of MIC and soluble phosphorus as well as a higher temperature. At the positive extreme are the January and February samples, along with nitrogen compounds and salinity. Component 2 separates April-September (biovolume and phosphorus vector, respectively), as well as separating November (salinity vector) from January-February (nitrate concentration vector; Figure 5a). 


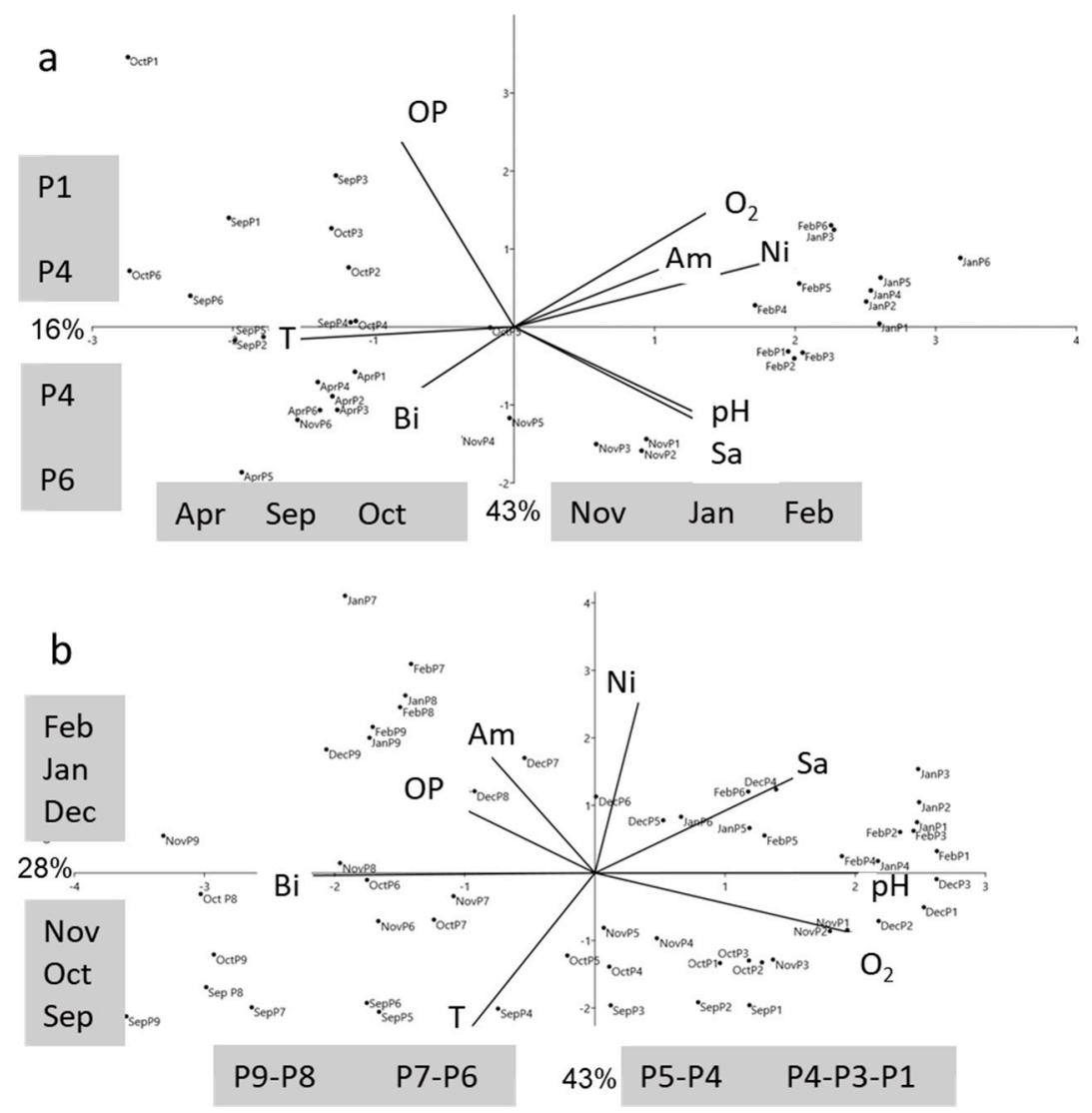

Figure 5. Principal component analysis of samples and limnological variables for (a) the Estero del Padre Ramos and (b) Estero Salinas Grandes data. Explained variance is shown in each axis. OP: Orthophosphate, $\mathrm{O}_{2}$ : Dissolved oxygen, Am: Ammonia, Ni: Nitrate, Sa: Salinity, T: Temperature, Bi: Biovolume. P1-P9 sampling sites.

The main taxonomic groups responsible for the MIC biovolume were Chlorophytes, Diatoms, Dinophytes and Cyanobacteria; these latter two with little presence. Euglenophytes were undetectable. The average density of Chlorophytes (Figure 6a) only exceeded $200 \mathrm{ind} / \mathrm{mL}$ in April when it reached $396 \pm 491 \mathrm{ind} / \mathrm{mL}$ (Figure 6a; Table S3). Populations belonging to seven different genera were found (Table S4), the most abundant, and also the most conspicuous, were Coenocystis, Crucigeniella, Monoraphidium and Dictyosphaerium. Diatoms showed their highest density in October and November $(372 \pm 173 \mathrm{ind} / \mathrm{mL}$ and $328 \pm 172 \mathrm{ind} / \mathrm{mL}$, respectively; Table S3). This is the group of algae with the greatest diversity; populations of 23 genera were found (Table S4). We found a pattern of population substitution over time which is related to the hydrological cycle. From September to November (rainy season) the most abundant populations belonged to the genera and species Biddulphia, Nitzschia (i.e., N. sigma and N. sinuata), Pleurosigma, Surirella and Skeletonema costatum. However, in January and February (dry season), the genera Aulacoseira and Navicula appeared as dominant. Only a few cyanobacteria individuals (Tables S3 and S4) were detected, and they were always filamentous, belonging to the genera Oscillatoria (in P1 in October) and Anabaena (in P3-P4 in January and February). Dinophyte peaks occurred in October and November $(2.6 \pm 1.3$ ind $/ \mathrm{mL}$ and $1.0 \pm 0.7 \mathrm{ind} / \mathrm{mL})$ and appeared along the estuary. For the rest of the months the average abundance of Dinophytes did not exceed 0.3 ind $/ \mathrm{mL}$. 

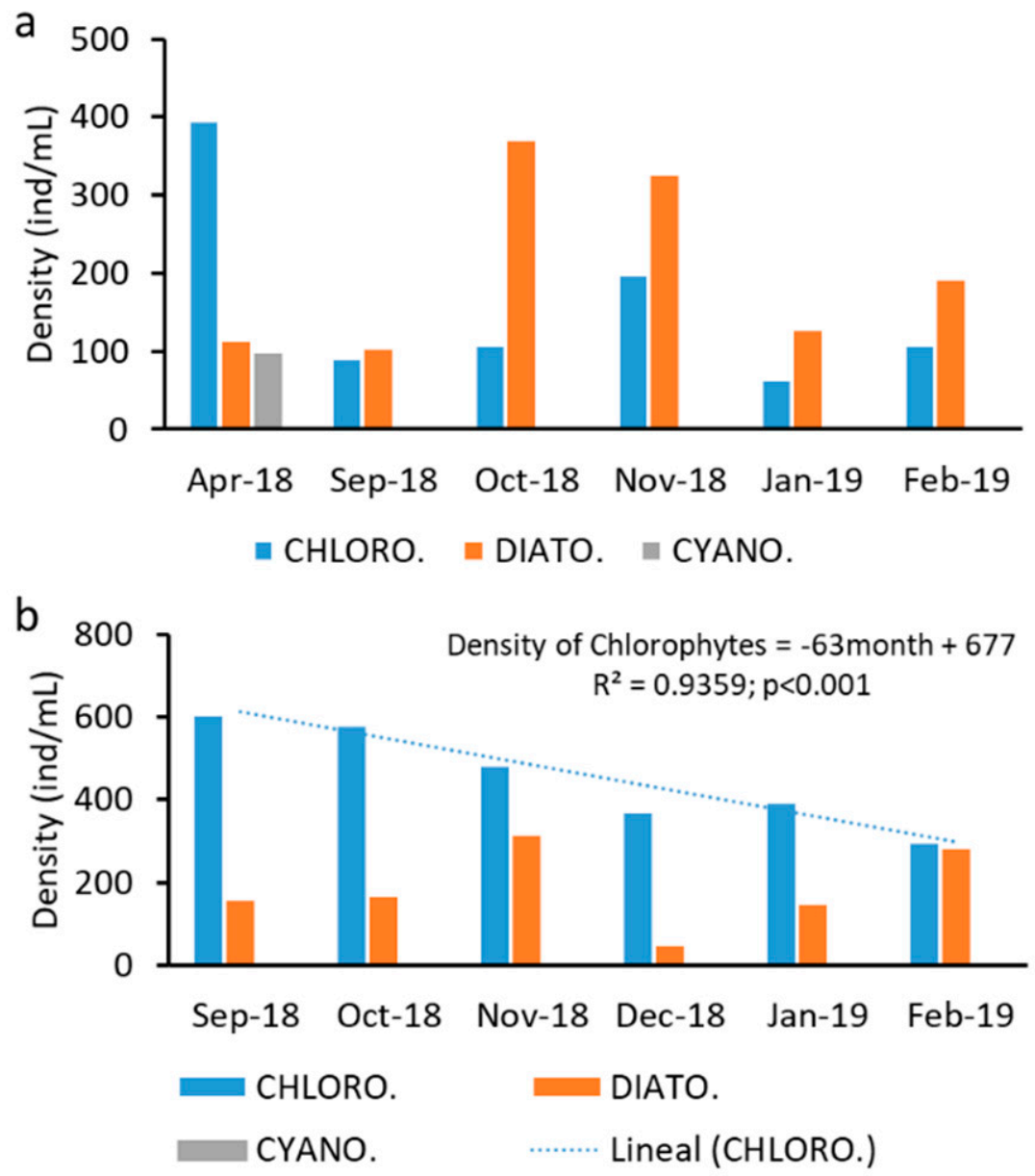

Figure 6. Density averages of MIC main groups in each sampling site from (a) Estero del Padre Ramos and (b) Estero Salinas Grandes. Values of means and their standard deviation are given in Table S3 (Supplementary material).

\subsection{Limnology of the Estero de Salinas Grandes}

The temperature range throughout the year studied, including all sites, was 26.1-30.4 ${ }^{\circ} \mathrm{C}$, the coldest months being January and February (Figure 7). An ANOVA analysis highlighted the temperature gradient (Table S2) from September to February (Figure 7). The $\mathrm{pH}$ range varied between 6.7-9.0, showing different periods (Table S2) and its maximum value was measured in November-December (average of both months $8.01 \pm 0.46$ ). The $\mathrm{DO}$ concentration range was $0.5-6.6 \mathrm{mg} / \mathrm{L}$ (Figure 7) and the differences between months were not significant. The oxygen concentration, as well as the $\mathrm{pH}$, was higher in the areas close to the mouth of the estuary, decreasing when moving towards the interior (Figure 7; Figure 1c). Salinity fluctuated between $10 \mathrm{ppm}$ and $35 \mathrm{ppm}$, and the annual means were significantly different (Figure 7; Table S2); from lowest to highest, the salinity ranges were: September $22.8 \pm 8.0 \mathrm{ppm}$, October and November values close to 30 ppm ( $30.1 \pm 2.8$ ppm, $29.9 \pm 3.3$ ppm, respectively), and January and February with a combined mean of $34.8 \pm 0.7 \mathrm{ppm}$. 

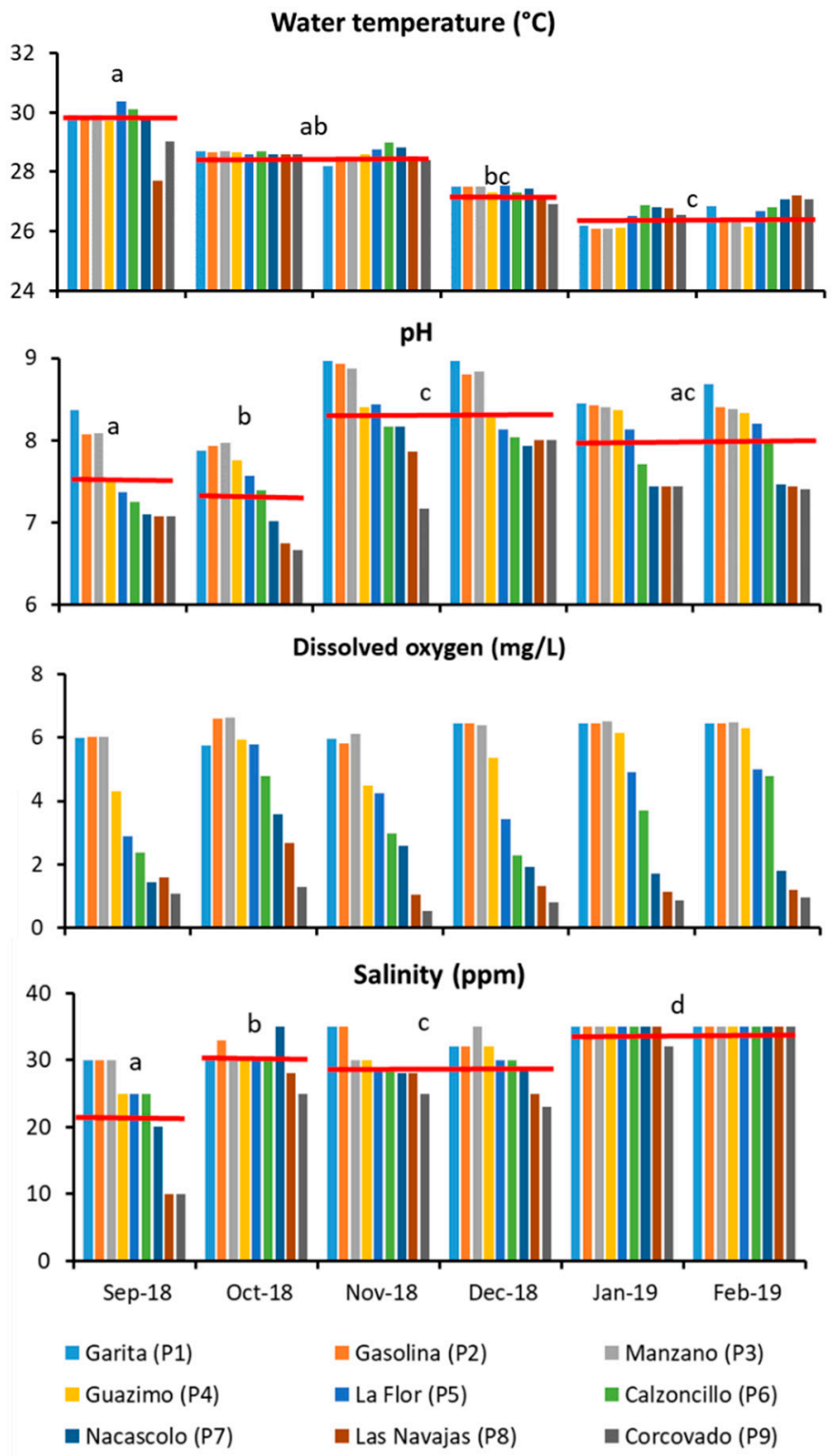

Figure 7. Physicochemical variables measured in the nine sites of the Estero Salinas Grandes. Red lines show the mean of each different group based on ANOVA results (Table S2; Supplementary material). The lower-case letters indicate significant differences in pairwise comparisons. Significant values when $p<0.001$.

The nitrate concentration was practically undetectable in the first sampling months (values lower than $0.1 \mathrm{mg} / \mathrm{L}$ and $11.8 \mathrm{mg} / \mathrm{L}$ (Figure 7). Moreover, large differences were observed between months (Table S2), with the months from December to January being similar (combined average of $6.6 \pm 3.0 \mathrm{mg} / \mathrm{L}$ ). The ammonium concentration was practically undetectable in all the samples, and the average of all of them was $0.10 \pm 0.27 \mathrm{mg} / \mathrm{L}$. Only in Nacascolo (P7) in January did it exceed $1 \mathrm{mg} / \mathrm{L}$ (Figure 8). The mean orthophosphate concentration ranged from $0.11 \pm 0.19 \mathrm{mg} / \mathrm{L}$ in September to $0.15 \pm 0.15 \mathrm{mg} / \mathrm{L}$ in February; however, these variations were not significantly different. It is noteworthy that in November in the first two sites the concentration of orthophosphate was undetectable, in December it was undetected in the first three sites, and in January and February it was in the first four sites. 


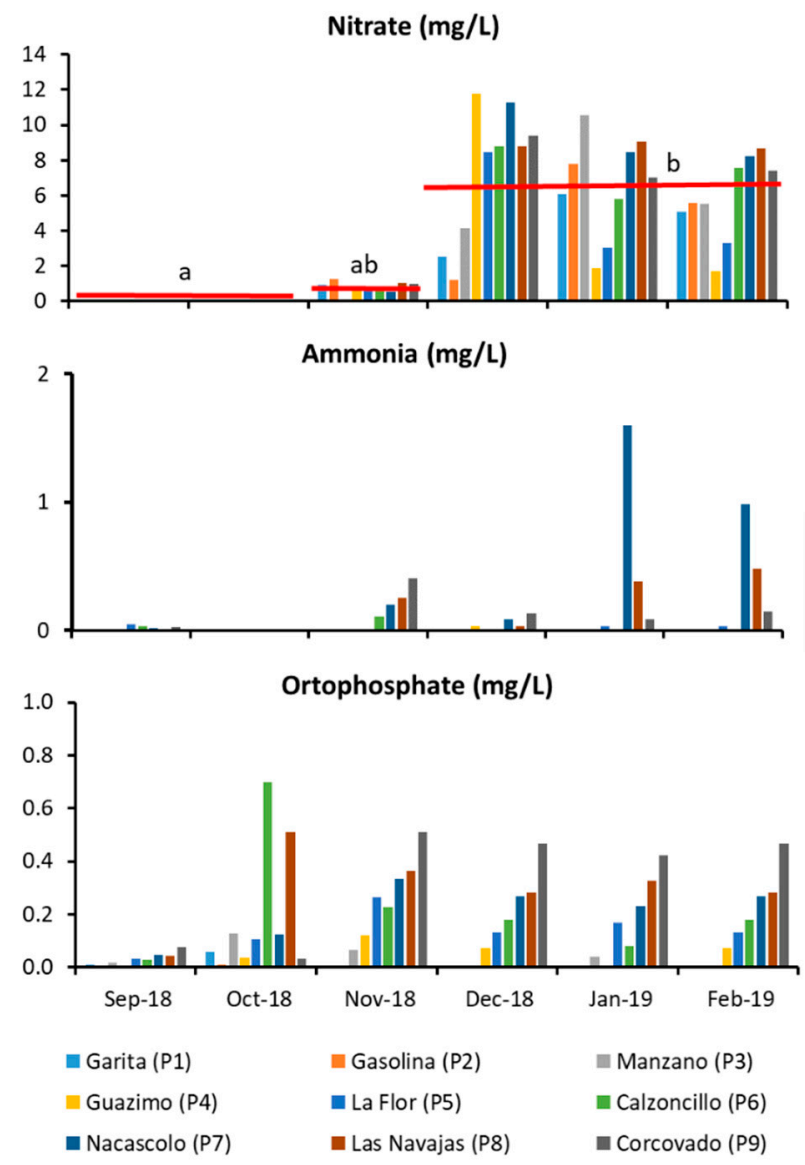

Figure 8. Nutrient concentrations measured in the nine sites of the Estero Salinas Grandes. Red bars show the mean of each different group based on ANOVA results (Table S2; Supplementary material). The lower-case letters indicate significant differences in pairwise comparisons. Significant values when $p<0.001$.

When the average concentration observed at all the sites was taken into account (Figure 9), the total MIC biovolume was significantly different between months. We can distinguish two sets $(\mathrm{F}=6.5 ; p<0.001)$ : September, October and November with a combined mean of $0.39 \pm 0.20 \mathrm{~mm}^{3} / \mathrm{L}$, and December, January and February which reached $0.25 \pm 0.17 \mathrm{~mm}^{3} / \mathrm{L}$ (Figure 9). Comparison of the average biovolume of all the months studied in each site shows us an ordering from lower to higher concentration as we move away from the estuary mouth (Figure 9). Thus, between P1 and P3 the average was $0.14 \pm 0.10 \mathrm{~mm}^{3} / \mathrm{L}$, and between $\mathrm{P} 8$ and $\mathrm{P} 9$ it was $0.54 \pm 0.10 \mathrm{~mm}^{3} / \mathrm{L}$. The estimated chlorophyll $a$ covaried significantly with the biovolume $\left(\mathrm{R}^{2} 0.98, p<0.001\right)$, and ranged from $1.52 \pm 0.06 \mu \mathrm{g} / \mathrm{L}$ from September to November to $2.10 \pm 0.11 \mu \mathrm{g} / \mathrm{L}$ in the period from December to February. The ordering in principal components of the samples from the ESG (Figure 5b) was spatial, and it ordered the samples based on their distance from the sea. In the positive part of component 1 were the sites closest to the outlet of the water from the estuary, together with the salinity vector and the oxygen concentration vector. At the opposite end were the samples from the sites farthest from the sea, together with a higher MIC biovolume. On the other hand, component 2 separated the months of December, January and February together with the nutrients of the months of September, October and November with higher temperatures (Figure $5 b$ ). 

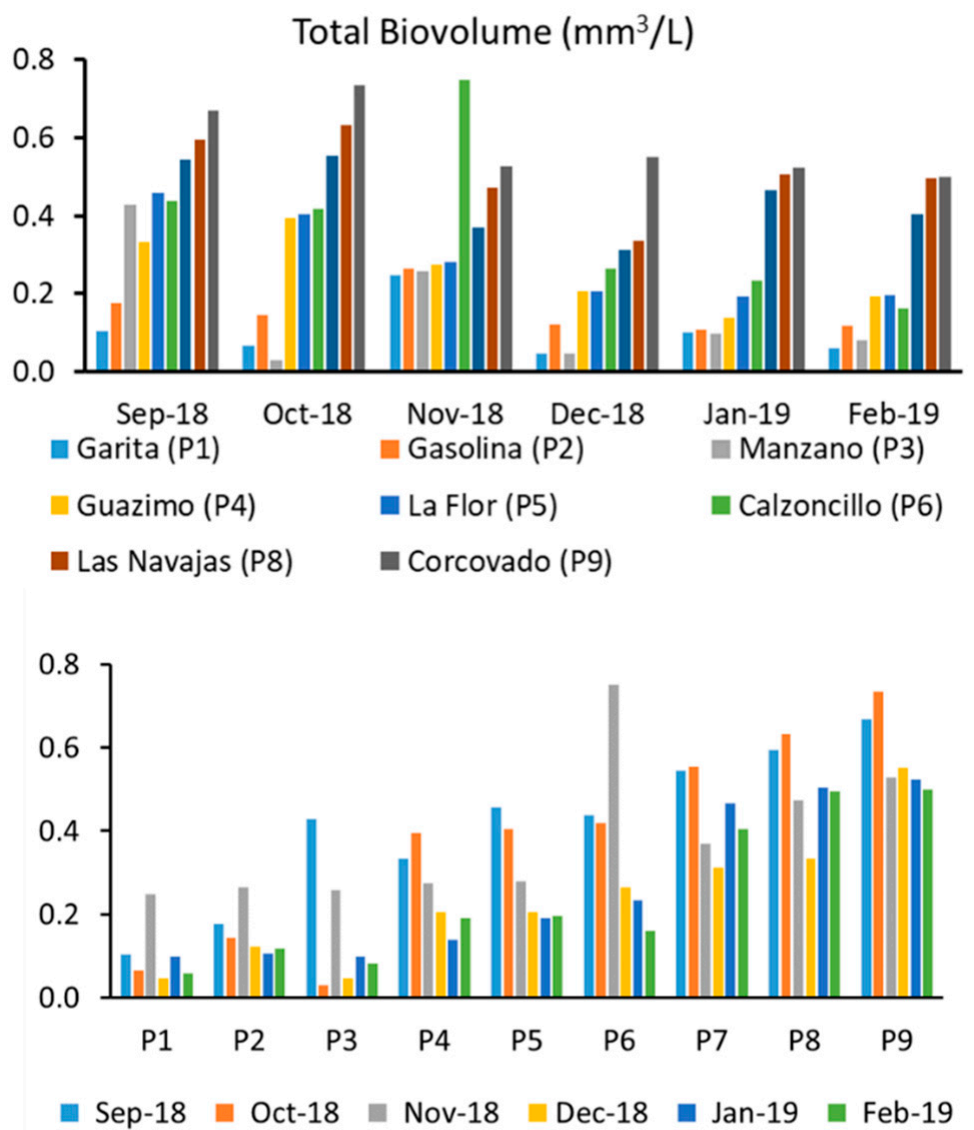

Figure 9. Biovolume of MIC (microalgae and cyanobacteria) observed in the nine sites of the Estero Salinas Grandes over the sampling period and temporal dynamics of biovolume in each site.

The main algal groups that made up the MIC biovolume in ESG were Chlorophyta and Bacillariophyta or Diatoms (Table S3). The presence of Dinophytes (Tripos fusus, less than 1 ind $/ \mathrm{mL}$ ) was only detected in February, and no cyanobacteria or Euglenophytes were found. The average Chlorophyta density of the locations in each month barely exceeded $600 \mathrm{ind} / \mathrm{mL}$, decreasing over the time period (Table S3). In total, 12 populations of 12 genera of Chlorophytes were found (Table S5). The most notable were Dictyosphaerium, Coenocystis and Monoraphidium for their abundance and occurrence (Figure 10). Diatoms do not show any trend over time (Table S3). Their density ranged from $50 \pm 40 \mathrm{ind} / \mathrm{mL}$ in December to $319 \pm 263$ ind $/ \mathrm{mL}$ in November, with the maximum value $(972 \mathrm{ind} / \mathrm{mL}$ ) being observed at $\mathrm{P} 6$, an intermediate point of the course of the estuary. This is the group of algae with the greatest diversity, and populations of 24 genera were found (Table S5). Aulacoseira granulata, Nitzschia sinuata and Surirella were the most remarkable (Figure 10). The CCA allowed us to discriminate a spatio-temporal pattern of the most abundant populations (Figure 10) with three possible associations: one that appears in the rainy September, the month with the highest temperature but also lowest levels of salinity and nutrients, and two other associations opposed to each other; one more related to nutrients and sites located a long way from the sea, and the other one to the sites closest to the sea and related to salinity (Figure 11). 


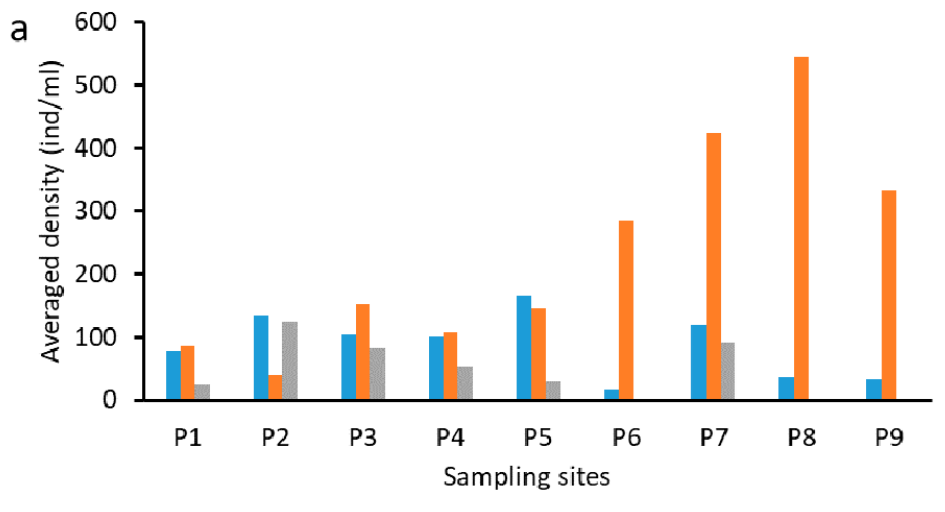

- Coenocystis Dictyosphaerium Monoraphidium

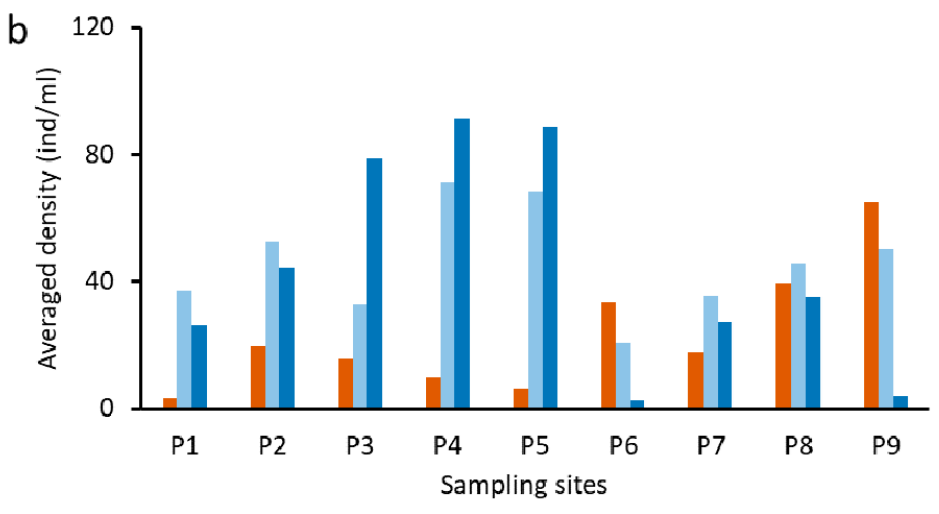

- Melosiragranulata Nitzschia sinuata $\square$ Surirella

Figure 10. Spatial distribution of temporal averaged density of main algae groups in Estero Salinas Grandes. (a) Chlorophytes, (b) Diatoms.

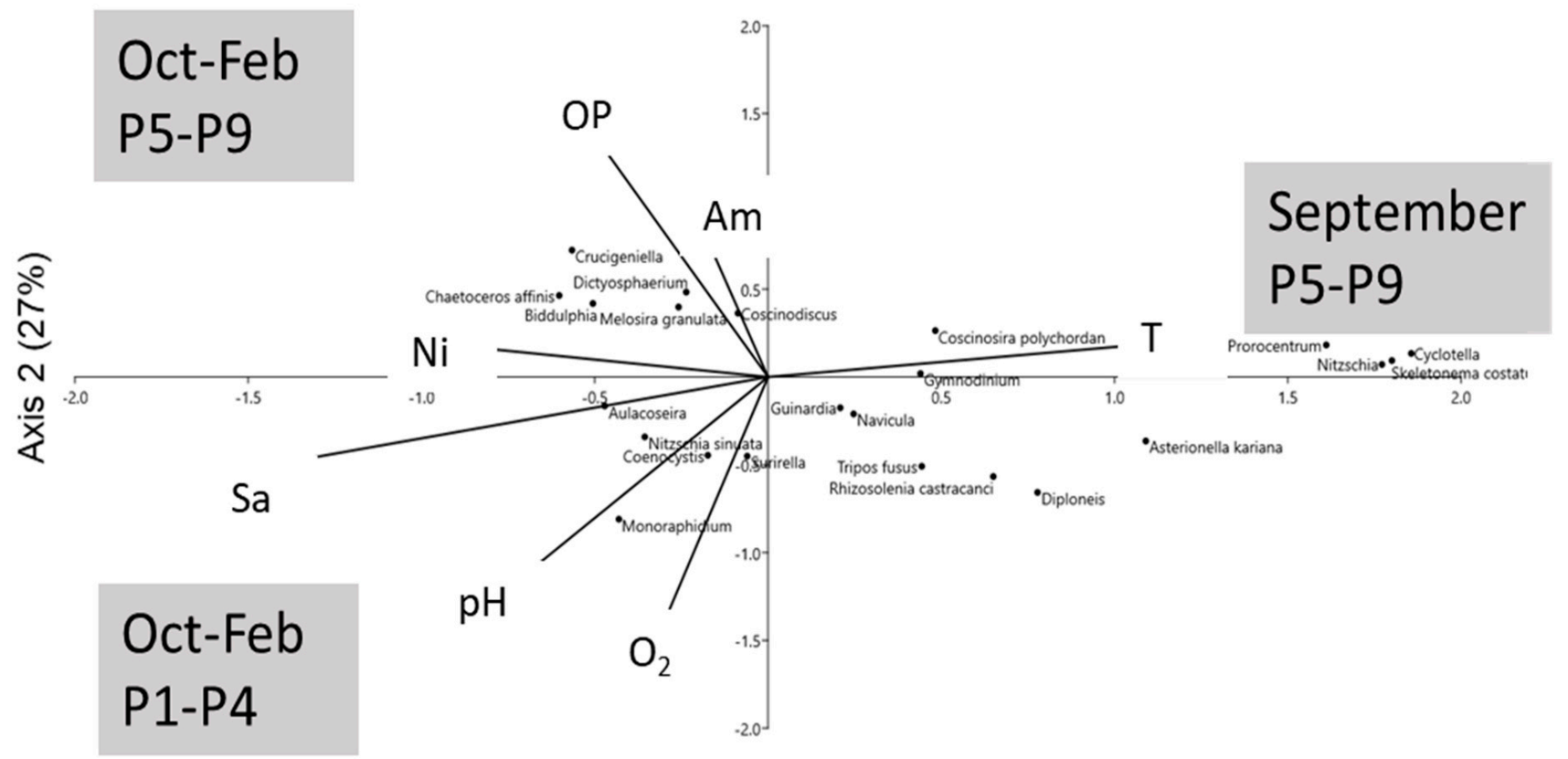

Axis $1(48 \%)$

Figure 11. CCA of samples, limnological variables and taxa obtained in Salinas Grandes. Explained variance is shown in each axis. Abbreviations as in Figure 5. Ordination by CCA of EPR data was not significant $(p<0.001)$. 


\section{Discussion}

In the EPR, features such as T, salinity, $\mathrm{pH}$ and dissolved oxygen do not vary spatially, and only respond to the hydrological season $[6,19]$, with a higher water temperature until September and greater salinity, $\mathrm{pH}$ and DO in the dry season from November to May. This same pattern is also found in the ESG, although in this estuary the effect of the dilution by the rains becomes more evident as we get closer to the estuary mouth. The concentrations of nutrients (mainly nitrate) obtained in the rainy season are much lower than those analyzed during the dry period; this indicates that the rains exert a dilution effect greater than a possible N contribution by runoff. In other estuaries, such as the Gulf of Nicoya, seasonal changes in nutrient concentrations (nitrate and dissolved orthophosphate), which were lower during the rainy season, were also observed [13], suggesting dilution by precipitation. This pattern is observed in both estuaries (EPR and ESG), and in both of them similar concentrations of $\mathrm{N}$ compounds are attained (i.e., approx. $8 \mathrm{mg} / \mathrm{L}$ of nitrate). During the dry period, the concentration of nitrates in the EPR is homogeneous. However, in the ESG the upper portion shows a higher concentration. The concentrations of orthophosphate in the ERP are very low, even undetectable on many occasions, so its high spatio-temporal irregularity warrants caution. However, in the ESG the concentration, which is ten times higher than that of the EPR, is lower in the rainy season and during the drought it is higher in the upper portion of the estuary. A spatio-temporal distribution similar to that found for nitrate. Therefore, we can suggest that we are dealing with estuaries in which the river has a greater effect than the ocean, and that in the rainy season, due to an increase in its flow rate into the sea, the compounds which the river obtains from the agricultural use in its catchment area are diluted.

In the EPR, the source of nutrients, mainly $\mathrm{N}$ compounds, is shrimp farming (Flores et al. 2007) which occupies $12 \%$ of the total area [6], practically up to the estuary mouth. Agriculture and livestock, which are present in its basin, occur on small farms for auto-consumption (peanuts, sugarcane, corn, chickens and pigs) and do not imply a great contribution of nutrients as they do not involve high levels of fertilization. However, in the ESG the nutrients, including phosphate, originate from the large areas devoted to corn cultivation (see these areas in Figure 1c). In fact, there are no changes in salinity that could explain changes in the behavior of the dissolved phosphorus [25], nor MIC growth, that could cause its decline [37]. The contribution of nutrients from these areas decreases towards the estuary mouth as the farm land gives way to the salt flats. There are some concerns about the possible nutrient supply from the snapper cages [47,48]. However, it can be stated that in none of the estuaries were differences in the nitrate concentration between the sites with and without cages, according to what had previously been observed in a snapper cage farm on the tropical coast of Mexico [14]. Furthermore, the average nitrate concentrations in the EPR and ESG $(9.2 \mathrm{mg} / \mathrm{L}$ and $6.6 \mathrm{mg} / \mathrm{L}$, respectively) were even lower than those of the aforementioned open-ocean floating cages $(12.3 \mathrm{mg} / \mathrm{L}-15.8 \mathrm{mg} / \mathrm{L}$; [14]). Phosphorous concentrations did not vary either between sites with or without cages, and their concentrations were low. The highest concentrations of phosphates were found in the sites furthest from the ESG coast during the dry months (on average $0.35 \pm 0.09 \mathrm{mg} / \mathrm{L}$ ), and the minimum value reported in the aforementioned study, which was observed at a site quite far from the cages, was $0.49 \pm 0.42 \mathrm{mg} / \mathrm{L}$ [14]. So, it can be stated that the cages were not altering the concentrations of dissolved nutrients. Our data support the notion that the undeniable exudate from these sets of cages is minimized by the rains for 6 months, and by sufficient tidal circulation and flushing in these open waters to the sea, as also suggested by [14].

The MIC biovolume and estimated chlorophyll $a$ concentration do not, at any time or in any place, exceed, in either of the two estuaries, the limit of $1 \mathrm{~mm}^{3} / \mathrm{L}$ (approx. $50 \mu \mathrm{gC} / \mathrm{L}$ ) or $2.5 \mu \mathrm{g} / \mathrm{L}$. These concentrations were lower than the minimum concentrations reported for the Gulf of Nicoya in the 2012 dry season (600 $\mu \mathrm{g} \mathrm{C/L}$ and $3 \mu \mathrm{g}$ Ch-a/L; [49]). Despite the differences between freshwater and estuarine systems, their similarities are sufficient for successful application of limnological modeling concepts to estuaries such the OECD 
model [50,51]. Therefore, with due caution, it can be stated that, according to [29] for the MIC biovolume, and the [30] for total chlorophyll $a$, the waters of both estuaries at all the sites, with or without snapper cages, and at any time of the hydrological year are oligotrophic. In addition, the spatial distribution of the biovolume of the phytoplankton seems to have a riverine rather than oceanic nutrient contribution, as already described, for example, for the Gulf of Nicoya [49], for a bar-built estuary in the northeastern Gulf of Mexico [52,53], or for the shallow low inflow estuary called Drakes Estero (California; [26]).

There is very little information on the dynamics of the taxonomic and functional groups of the MIC on the estuaries of the Pacific coast of Nicaragua (except for the specific works carried out by students of the University of Nicaragua). Reviewing the information on the most-studied tropical and subtropical Pacific coast estuaries, such as the externaloceanic or internal-fluvial zones of the Gulf of Nicoya (e.g., $[13,39,54]$ or in the Gulf of Papagayo in Costa Rica [55], we can see that hydrology (river flow, flushing and tidal extension) and nutrients conditioned by hydrology are the main control factors of MIC groups. In the aforementioned estuaries, Chlorophytes are not relevant nor are they included in broad functional groups such as small flagellates (mainly Prasinophytes). Diatoms (centric and pennate) and Dinoflagellates are the groups that receive the most attention, followed by cyanobacteria, although the density of the latter is always low [13,54,55]. In the EPR and ESG, the composition of MIC assemblages varies throughout the hydrological year, but the lack of a longer time series prevents us from knowing if there is a temporal pattern of substitution, such as those described for temperate ecosystems [37]. In tropical and subtropical environments, it is recognized that the marked effect of the long rainy season functions as a great disturbance that reinitiates the dynamics of phytoplankton $[20,56]$. For now, we can suggest a pattern that takes into account the MIC variations in both studied estuaries. Diatoms do not show any trend over time, as observed in the Gulf of Nicoya [39]; and they were somewhat more abundant at two moments of the hydrological year: at the end of the rainy season (October to November), which is the period considered to be the transition to the dry season, and in the middle of the dry season (February). Chlorophytes, more typical of fresh water, were more abundant at the end of the dry season (April and September) and they decreased as the rainy season progressed. As for cyanobacteria, the most relevant thing is their scarcity, indicating that there are no large foci of eutrophication, or specific allochthonous contributions that may favor their bloom [8,57]. The dinoflagellates appear mainly at the time of transition from rain to drought and appeared throughout the estuary, therefore they do not seem to be linked to the most coastal zone as in the Gulf of Nicoya [13]. The densities reached by diatoms in the EPR and ESG are comparable to those mentioned for the interior of the Gulf of Nicoya (average $186 \pm 159 \mathrm{ind} / \mathrm{mL}$ and $130 \pm 23 \mathrm{ind} / \mathrm{mL}$, respectively; [13]), but much lower than those that occur in its external area [39]. The density of toxic dinoflagellates is directly related to greater eutrophication of the coast $[22,58]$ and a contribution of this coastal water to the estuary [13]. Thus, in the marine area of the Gulf of Nicoya, an annual average density of $59 \pm 9 \mathrm{ind} / \mathrm{mL}$ has been described [39], and in the interior of the estuary, the density of dinoflagellates does not exceed $25 \mathrm{ind} / \mathrm{mL}$ [13]. Therefore, we can consider that the lack of eutrophication, and the fluvial nature of the ERP and ESG, protect them from the growth of these toxic dinoflagellates along their course, since they did not exceed $3 \mathrm{ind} / \mathrm{mL}$. The presence and distribution of all these taxonomic groups reinforces the idea that the EPR and ESG have an even more marked fluvial character than other tropical estuaries dominated by freshwater influence in the Pacific [13] and Atlantic coasts, such as the estuary of the Paraíba do Sul River in Brazil [56].

Regarding the genera, and sometimes species, in EPR and ESG the most abundant and conspicuous populations of Chlorophytes were small freshwater (i.e., Dictyosphaerium, Coenocystis, Monoraphidium) planktonic organisms (nanoplankton), whose highest densities were found in the upper estuary; all this is consistent with the strategy of fast growing microalgae favored by higher river flow rates [56]. Among the diatoms there were purely planktonic genera such as Cyclotella and benthic organisms which are captured in the water 
column due to their detachment from the sediment by dragging. Diatoms were made up of genera mostly from brackish and marine environments. The species recognized as being from brackish environments (Nitzschia sinuata and Surirella) were the most conspicuous between September and November (rainy season and transition to drought) and more abundant in the central points of the estuary. In the period from January and February, which is the period of advanced drought, genera more typical of fresh waters appear, such as the centric diatom Aulacoseira granulata. Again we see that the drought does not propitiate a greater marine intrusion related to upwelling, nor a change towards assemblages of marine water species as described in those characterized as seasonal lowinflow estuaries adjacent to coastal upwelling [2]. The observed cyanobacteria populations that were observed were always filamentous specimens of the Oscillatoria and Anabaena genera. The former are planktonic organisms that are not N-fixers, whilst the latter are benthic N-fixers, which can be related to a drag from the benthos [59]. Both genera have potentially toxic brackish and freshwater species [60]; but the amounts in which they have been found are far from worrying [61]. In the ESG, the presence of Dinoflagellates of the species Tripos fusus was only detected occasionally during the drought period, as occurred in the Gulf of Papagayo (Costa Rica, [55]). The most abundant populations in the EPR belonged to the Noctiluca (i.e., Noctiluca cf. scintillans), Pyrodinium and Cochlodinium genera. Most of the populations found can be considered harmful marine environment algae (Table S4) and have been cited as common in tropical estuaries such as the Gulf of Mexico, and those in the tropical Pacific such as the Gulf of Nicoya, the Gulf of California [39,62-64] or in the Gulf of Thailand in the South China Sea [65].

\section{Conclusions}

Our study shows that there are estuaries on the Pacific Coast of Nicaragua with excellent water quality (oligotrophy and absence of harmful organisms) due to their fluvial character. During the rainy season, there occurred a decrease in water compounds and microorganisms. In the dry period nutrients and salinity enhanced different assemblages of microscopic primary producers. Nutrient inputs from shrimp farms, farms, crops and snapper cages did not appear to cause eutrophication and cyanobacterial blooms were avoided. On the other hand, the river influence seemed to prevent the entry of harmful dinoflagellates from the marine area.

Supplementary Materials: The following are available online at https://www.mdpi.com/article/10 $.3390 / w 13121712$ /s1, Table S1: Name of sampled sites and their coordinates in Estero Padre Ramos and Estero Salinas Grande (Nicaragua). When in the site there are a cage of culture of Lutjanus spp. their installation data is indicated, Table S2: Results of repeated measures ANOVA (F and post-hoc Tukey's pairwise test) or H de Kruskal-Wallis (post-hoc Mann-Whitney's test) comparing values of physico-chemical variables between sampling data and between sampling sites. The lower-case letters indicate significant differences in pair-wise comparisons. Significant values when $p<0.001$, Table S3: Mean and standard deviation of density (ind $/ \mathrm{mL}$ ) of main MIC groups in both studied estuaries (Estero de Padre Ramos and Estero de Salinas Grandes). Cyanobacteria and Dinophytes were undetectable in Estero Salinas Gandres, Table S4: Genera and some species of microalgae and Cyanobacteria observed in samples of Estuario de Padre Ramos. It is reported their reached maxima density and percentage, their occurrence as percentage of samples where they were found, their more probable functional group and habitat and their potential toxicity, Table S5: Genera and some species of microalgae and Cyanobacteria observed in samples of Estuario Salinas Grandes. It is reported their reached maxima density and percentage, their occurrence as percentage of samples where they were found, their more probable functional group and habitat and their potential toxicity.

Author Contributions: Conceptualization, C.R. and A.A.; methodology, A.A., C.R., D.L., K.O., K.P. and P.R.; data analysis, C.R. and D.L.; resources, A.A., C.R., P.R.; writing-original draft preparation, C.R. and D.L. All authors have read and agreed to the published version of the manuscript.

Funding: This research work was developed with funds from the project "Strengthening capacities for the rearing and fattening of snapper (Lutjanus spp.) in floating cages in 8 Nicaraguan coastal communities", subsidized by the Spanish Agency for International Development Cooperation (AE- 
CID). In addition, the following NGOs, Fundación LIDER, Fauna and Flora International (FFI) and Foundation Ecology and Development (ECODES) subsidized the trips along the estuaries.

Institutional Review Board Statement: Not applicable.

Informed Consent Statement: Not applicable.

Data Availability Statement: The data presented in this study will be made available on request from the corresponding author.

Conflicts of Interest: The authors declare no conflict of interest.

\section{References}

1. Oppenheimer, M.; Campos, M.; Warren, R.; Birkmann, J.; Luber, G.; O’Neill, B.; Takahashi, K.; Brklacich, M.; Semenov, S.; Licker, R.; et al. Emergent risks and key vulnerabilities. In Climate Change 2014 Impacts, Adaptation and Vulnerability: Part A: Global and Sectoral Aspects; Cambridge University Press: Cambridge, UK, 2015; pp. 1039-1100.

2. Wilson, J.R.; Wilkerson, F.P.; Blaser, S.B.; Nielsen, K.J. Phytoplankton community structure in a seasonal low-inflow estuary adjacent to coastal upwelling (Drakes Estero, CA, USA). Estuaries Coasts 2021, 44, 769-787. [CrossRef]

3. Osland, M.J.; Enwright, N.M.; Day, R.H.; Gabler, C.A.; Stagg, C.L.; Grace, J.B. Beyond just sea-level rise: Considering macroclimatic drivers within coastal wetland vulnerability assessments to climate change. Glob. Chang. Biol. 2016, 22, 1-11. [CrossRef]

4. Vammen, K.; Peña, E.; García, I.; Sandoval, E.; Jiménez, M.; Cornejo, I.A.; Salvatierra, T.; Zamorio, M.J.; Wheelock, C.; Baltodano, A.; et al. The challenges of protecting water quality in Nicaragua. In Water Quality in the Americas Risks and Opportunities; The Inter-American Network of Academies of Sciences (IANAS-IAP): Mexico City, México, 2019; p. 635.

5. IANAS. Calidad de Aguas en las Américas, Riesgos y Oportunidades; UNESCO: Mexico City, México, 2019.

6. Jameson, S.C.; Stevens, K.; Bennett, R.C.; Cardoza, N.J.T. Nicaragua: Pacific Coast. In World Seas, an Environmental Evaluation; Elsevier: Amsterdam, The Netherlands, 2019; pp. 743-757.

7. United Nations. La Temporada 2020 de Huracanes en el Atlántico: Un Récord y una Tragedia para Centroamérica. 2020. Available online: https:/ / news.un.org/es/story/2020/11/1484192 (accessed on 20 June 2021).

8. Metcalf, J.S.; Banack, S.A.; Wessel, R.A.; Lester, M.; Pim, J.G.; Cassani, J.R.; Cox, P.A. Toxin analysis of freshwater cyanobacterial and marine harmful algal blooms on the West coast of Florida and implications for estuarine environments. Neurotox. Res. 2021, 39, 27-35. [CrossRef] [PubMed]

9. World Health Organization. Website on “One Health”. 2017. Available online: https://www.who.int/news-room/q-adetail/ one-health (accessed on 20 June 2021).

10. Gocke, K.; Cortés, J.; Murillo, M.M. Planktonic primary production in a tidally influenced mangrove forest on the Pacific coast of Costa Rica. Rev. Biol. Trop. 2001, 49 (Suppl. 2), 279-288.

11. Córdoba-Muñoz, R. Primary productivity in the water column of Estero Morales, a mangrove system in the Gulf of Nicoya, Costa Rica. Rev. Biol. Trop. 1998, 46 (Suppl. 6), 257-262.

12. Gómez-Ramírez, E.H.; Corzo, A.; García-Robledo, E.; Bohórquez, J.; Agüera-Jaquemet, A.; Bibbó-Sánchez, F.; Soria-Píriz, S.; Jiménez-Arias, J.A.; Morales, A.; Papaspyrou, S. Benthic-pelagic coupling of carbon and nitrogen along a tropical estuarine gradient (Gulf of Nicoya, Costa Rica). Est. Coast. Shelf Sci. 2019, 228, 106362. [CrossRef]

13. Seguro, I.; García, C.M.; Papaspyrou, S.; Gálvez, J.A.; García-Robledo, E.; Navarro, G.; Soria-Píriz, S.; Aguilar, V.; Lizano, O.G.; Morales-Ramírez, A.; et al. Seasonal changes of the microplankton community along a tropical estuary. Reg. Stud. Mar. Sci. 2015, 2, 189-202. [CrossRef]

14. Vargas-Machuca, S.C.; Ponce-Palafox, J.T.; Arredondo-Figueroa, J.L.; Chávez-Ortiz, E.A.; Vernon-Carter, E.J. Physico-chemical water parameters variation in the floating cages of snappers (Lutjanus peru and L. guttatus) farmed in tropical sea. Rev. Mex. Ing. Quim. 2008, 7, 237-242.

15. Band-Schmidt, C.J.; Bustillos-Guzmán, J.J.; López-Cortés, D.J.; Gárate-Lizárraga, I.; Núñez-Vázquez, E.; Hernández-Sandoval, F.E. Ecological and physiological studies of Gymnodinium catenatum in the Mexican Pacific: A review. Mar. Drugs 2010, 8, $1935-1961$. [CrossRef] [PubMed]

16. Benessaiah, K.; Sengupta, R. How is shrimp aquaculture transforming coastal livelihoods and lagoons in Estero Real, Nicaragua? The need to integrate social-ecological research and ecosystem-based approaches. Env. Manag. 2014, 54, 162-179. [CrossRef]

17. Carvalho, F.P.; Montenegro-Guillén, S.; Villeneuve, J.P.; Cattini, C.; Bartocci, J.; Lacayo, M.; Cruz, A. Chlorinated Hydrocarbons in Coastal Lagoons of the Pacific Coast of Nicaragua. Arch. Env. Contam. Toxicol. 1999, 36, 132-139. [CrossRef]

18. Huete-Pérez, J.A.; Mendoza-Ramírez, E.; Páiz-Medina, L. Genomic biorepository of coastal marine species in Estero Padre Ramos and Estero Real, Nicaragua. Encuentro 2002, 93, 6-18. [CrossRef]

19. Sasa, M.; Armengol, X.; Bonilla, F.; Mesquita-Joanes, F.; Piculo, R.; Rojo, C.; Rueda, R.M.; Monrós, J.M. Seasonal wetlands in the Pacific coast of Costa Rica and Nicaragua: Environmental characterisation and conservation state. Limnetica 2015, 34, 1-16.

20. Rojo, C.; Mesquita-Joanes, F.; Monrós, J.S.; Armengol, J.; Sasa, M.; Bonilla, F.; Rueda, R.; Benavent-Corai, J.; Piculo, R.; Segura, M.M. Hydrology affects environmental and spatial structuring of microalgal metacommunities in tropical Pacific Coast wetlands. PLoS ONE 2016, 11, e0149505. [CrossRef] 
21. Vargas-Montero, M.; Freer, E. Proliferaciones algales nocivas de cianobacterias (Oscillatoriaceae) y dinoflagelados (Gymnodiniaceae) en el Golfo de Nicoya, Costa Rica. Rev. Biol. Trop. 2004, 52, 121-125. [PubMed]

22. Vargas Montero, M.; Freer Bustamante, E.; Guzmán, J.C.; Carlos Vargas, J. Harmful blooms by noxious dinoflagellates in the Pacific coast of Costa Rica. Hidrobiologica 2008, 18, 15-23.

23. De Senerpont Domis, L.; Elser, J.J.; Gsell, A.S.; Huszar, V.L.M.; Ibelings, B.W.; Jeppesen, E.; Kosten, S.; Mooij, W.M.; Roland, F.; Sommer, U.; et al. Plankton dynamics under different climatic conditions in space and time. Freshwat. Biol. 2013, 58, 463-482. [CrossRef]

24. Cotovicz Junior, L.; Machado, E.C.; Brandini, N.; Zem, R.C.; Knoppers, B.A. Distributions of total, inorganic and organic phosphorus in surface and recent sediments of the sub-tropical and semi-pristine Guaratuba Bay estuary, SE Brazil. Environm. Earth Sci. 2014, 72, 373-386. [CrossRef]

25. Trott, L.A.; Alongi, D.M. The impact of shrimp pond effluent on water quality and phytoplankton biomass in a tropical mangrove estuary. Mar. Pollut. Bull. 2000, 40, 947-951. [CrossRef]

26. Buck, C.M.; Wilkerson, F.P.; Parker, A.E. The influence of coastal nutrients on phytoplankton productivity in a shallow low inflow estuary, Drakes Estero, California (USA). Estuaries Coasts 2014, 37, 847-863. [CrossRef]

27. AECID. Fortalecimiento de Capacidades para la Cría y Engorde en Jaulas Flotantes de Pargo (Lutjanus spp.) en 8 Comunidades Costeras de Nicaragua. 2018. Available online: http:/ / www.aecid.org.ni/crianza-de-pargo-en-esteros-mejorara-la-vida-depescadores-artesanales-de-el-viejo-y-leon/ (accessed on 20 June 2021).

28. Vammen, K.; Hurtado, I. Los Recursos Hídricos de Nicaragua; CEPAL: 2010. Available online: http:/ / coin.fao.org/coin-static/ cms/media/5/12820625348650/fao_nic_recursoshidricos_cepal.pdf (accessed on 20 June 2021).

29. Willén, E. Phytoplankton water quality assessment-an indicator concept. In Hydrological and Limnological Aspects of Lake Monitoring; Heinonen, H., Ziglio, G., Van der Beken, A., Eds.; John Wiley and Sons: Hoboken, NJ, USA, 2000; pp. 58-80.

30. OECD. Eutrophication of Waters. Monitoring, Assessment and Control. In Cooperative Programme on Monitoring of Inland Waters (Eutrophication Control); Environment Directorate: Paris, France, 1982.

31. Casé, M.; Eskinazi Leça, E.; Neumann, S.; Eskinazi Sant'Anna, E.; Schwamborn, R.; Travassos de Moraes, A. Plankton community as an indicator of water quality in tropical shrimp culture ponds. Mar. Poll. Bull. 2008, 56, 1343-1352. [CrossRef] [PubMed]

32. Staples, D.; Funge-Smith, S. Ecosystem Approach to Fisheries and Aquaculture: Implementing the FAO Code of Conduct for Responsible Fisheries; FAO Regional Office for Asia and the Pacific: Bangkok, Thailand, 2009; p. 48.

33. Asociación para la Sobrevivencia y el Desarrollo Local (ASODEL). Proyecto Bosai, Informe Línea de Base Sobre Vulnerabilidad en la Comunidad Salinas Grandes. Available online: http: / /asodel.org/?mdocs-file=4509 (accessed on 20 June 2021).

34. Centro de Investigación de Ecosistemas Acuáticos (CIDEA). Línea de Base y Referencia de Governance para Padre Ramos; CIDEA: Abingdon, UK, 2005. Available online: http://repositorio.uca.edu.ni/2274/1/2006_linea_de_basa_Padre_Ramos_final.pdf (accessed on 20 June 2021).

35. Nesterenko, E.P.; Murphy, B.; Murray, E.; Moore, B.; Diamond, D. Solid-phase test reagent for determination of nitrite and nitrate. Anal. Methods 2016, 8, 6520-6528. [CrossRef]

36. Jain, R.; Thakur, A.; Kumar, P.; Pooja, D. Materials in colorimetric detection of water pollutants. In Sensors in Water Pollutants Monitoring: Role of Material. Advanced Functional Materials and Sensors; Pooja, D., Kumar, P., Singh, P., Patil, S., Eds.; Springer: Singapore, 2020.

37. Reynolds, C.S. The Ecology of Freshwater Phytoplankton; Cambridge University Press: Cambridge, UK, 1988.

38. Rojo, C.; Álvarez-Cobelas, M.; Benavent-Corai, J. Trade-offs in plankton species richness arising from drought: Insights from long-term data of a National Park wetland (central Spain). Biodivers. Conserv. 2012, 21, 2453-2476. [CrossRef]

39. García-Rojas, A.; Vega Bolaños, H. Cambios estacionales del fitoplancton en el área marina de pesca responsable de PaqueraTambor, Golfo de Nicoya, Costa Rica. Rev. Mar. Cost. 2016, 8, 29-45. [CrossRef]

40. Guamán, M.; González, N. Catálogo de Microalgas y Cianobacterias de Agua Dulce del Ecuador; Corporación para la Investigación Energética: Cuenca, Ecuador, 2016; p. 143.

41. Hasle, G.; Syvertsen, E. Marine diatoms. In Identifying Marine Diatoms and Dinoflagellates; Tomas, C., Ed.; Academic Press: San Diego, CA, USA, 1996.

42. Serfling, R. Quantitative estimates of plankton from small samples of Sedgwick-Rafter cell mounts of concentrate samples. Trans. Am. Microsc. Soc. 1949, 68, 185-199. [CrossRef]

43. Rott, E. Some results from phytoplankton counting intercalibration. Schweiz. Z. Hydrol. 1981, 43, $34-62$.

44. Parinet, B.; Lhote, A.; Legube, B. Principal component analysis: An appropriate tool for water quality evaluation and management-Application to a tropical lake system. Ecol. Model. 2004, 178, 295-311. [CrossRef]

45. Legendre, P.; Legendre, L. Numerical Ecology, 2nd ed.; Elsevier: Amsterdam, The Netherlands, 1998 ; p. 853.

46. Hammer, Ø.; Harper, D.A.T.; Ryan, P.D. PAST: Paleontological statistics software package for education and data analysis. Palaeontol. Electron. 2001, 4, 9. Available online: http://palaeo-electronica.org/2001_1/past/issue1_01.htm (accessed on 20 June 2021).

47. Holby, O.; Hall, P. Chemical fluxes and mass balances in a marine fish cage farm. II Phosphorus. Mar. Ecol. Prog. Ser. 1991, 70, 263-272. [CrossRef]

48. Hall, P.; Anderson, L.; Holby, O.; Kollberg, S.; Samuelsson, M.-O. Chemical fluxes and mass balances in a marine fish cage farm. I Carbon. Mar. Ecol. Prog. Ser. 1990, 61, 61-73. [CrossRef] 
49. Soria-Píriz, S.; Garcia-Robledo, E.; Papaspyrou, S.; Aguilar, V.; Seguro, I.; Acuña, J.; Morales, Á.; Corzo, A. Size fractionated phytoplankton biomass and net metabolism along a tropical estuarine gradient. Limnol. Oceanogr. 2017, 62, S309-S326. [CrossRef]

50. Neilson, B.J.; Cronin, L.E. Estuaries and Nutrients; Neilson, B.J., Cronin, L.E., Eds.; Humana Press: Clifton, NJ, USA, 1981 ; p. 643.

51. Steward, J.S.; Lowe, E.F. General empirical models for estimating nutrient load limits for Florida's estuaries and inland waters. Limnol. Oceanogr. 2009, 55, 433-445. [CrossRef]

52. Oczkowski, A.; Lewis, F.; Nixon, S.; Edmiston, H.; Robinson, R.; Chanton, J. Fresh water inflow and oyster productivity in Apalachicola Bay, FL (USA). Estuaries Coasts 2011, 34, 993-1005. [CrossRef]

53. Mortazavi, B.; Iverson, R.L.; Huang, W.; Lewis, F.G.; Caffrey, J.M. Nitrogen budget of Apalachicola Bay, a bar-built estuary in the northeastern Gulf of Mexico. Mar. Ecol. Prog. Ser. 2000, 195, 1-14. [CrossRef]

54. Brugnoli, O.E.; Morales Ramírez, A. La comunidad fitoplanctónica de Punta Morales, Golfo de Nicoya, Costa Rica. Rev. Biol. Trop. 2001, 49 (Suppl. 2), 11-17.

55. Loza Álvarez, S.; Benavides-Morera, R.; Brenes-Rodríguez, C.L.; Ballestero-Saxon, D. Estructura del fitoplancton en las épocas seca y lluviosa en el golfo de Papagayo, Costa Rica. Rev. Mar. Cost. 2018, 10. [CrossRef]

56. Costa, L.S.; Huszar, V.L.M.; Ovalle, A.R. Phytoplankton Functional Groups in a Tropical Estuary: Hydrological Control and Nutrient Limitation. Chesap. Sci. 2009, 32, 508-521. [CrossRef]

57. Metcalf, J.S.; Banack, S.A.; Powell, J.T.; Tymm, F.J.M.; Murch, S.J.; Brand, L.E.; Cox, P.A. Public health responses to toxic cyanobacterial blooms: Perspectives from the 2016 Florida event. Water Policy 2018, 20, 919-932. [CrossRef]

58. López-Cortés, D.J.; Núñez-Vázquez, E.J.; Dorantes-Aranda, J.J.; Band-Schmidt, C.J.; Hernández-Sandoval, F.J.; Bustillos-Guzmán, J.J.; Leyva-Valencia, I.; Hernández-Herrera, L.J. The state of knowledge of harmful algal blooms of Margalefidium polykrikoides (a.k.a. Cochlodinium polykrikoides) in Latin America. Front. Mar. Sci. 2019, 6, 463. [CrossRef]

59. Bouma-Gregson, K.; Power, M.E.; Bormans, M. Rise and fall of toxic benthic freshwater cyanobacteria (Anabaena spp.) in the Eel river: Buoyancy and dispersal. Harmful Algae 2017, 66, 79-87. [CrossRef]

60. Carmichael, W.R.; Mahmood, N.A.; Hyde, E.G. Cellular mechanisms of action for freshwater Cyanobacteria (blue-green algae) toxins. In Microbial Toxins in Food and Feeds; Pohland, A.E., Dowell, V.R., Jr., Richard, J.L., Cole, R.J., Eklund, M.W., Green, S.S., Norred, W.P., III, Potter, M.E., Eds.; Springer: Dordrecht, Germany, 1990; pp. 553-573.

61. Chorus, I.; Bartram, J. OMS. Toxic Cyanobacteria in Water. A Guide to Their Public Health Consequences, Monitoring and Management; Chapman and Hall: London, UK, 1999.

62. Escobar-Morales, S.; Hernández-Becerril, D.U. Free-living marine planktonic unarmoured dinoflagellates from the Gulf of Mexico and the Mexican Pacific. Bot. Mar. 2015, 58, 9-22. [CrossRef]

63. Gárate-Lizárraga, I. Dinoflagelados desnudos presentes durante un florecimiento de Ceratoperidinium falcatum en Bahía de La Paz, Golfo de California. Rev. Biol. Mar. Oceanogr. 2014, 49, 577-587. [CrossRef]

64. Morquecho, L.; Alonso-Rodriguez, R.; Martinez-Tecuapacho, G.A. Cyst morphology, germination characteristics, and potential toxicity of Pyrodinium bahamense in the Gulf of California. Bot. Mar. 2014, 57, 303-314. [CrossRef]

65. Sriwoon, R.; Pholpunthin, P.; Lirdwitayaprasit, T.; Kishino, M.; Furuya, K. Population dynamics of green Noctiluca scintillans (Dinophyceae) associated with the monsoon cycle in the upper Gulf of Thailand. J. Phycol. 2008, 44, 605-615. [CrossRef] [PubMed] 